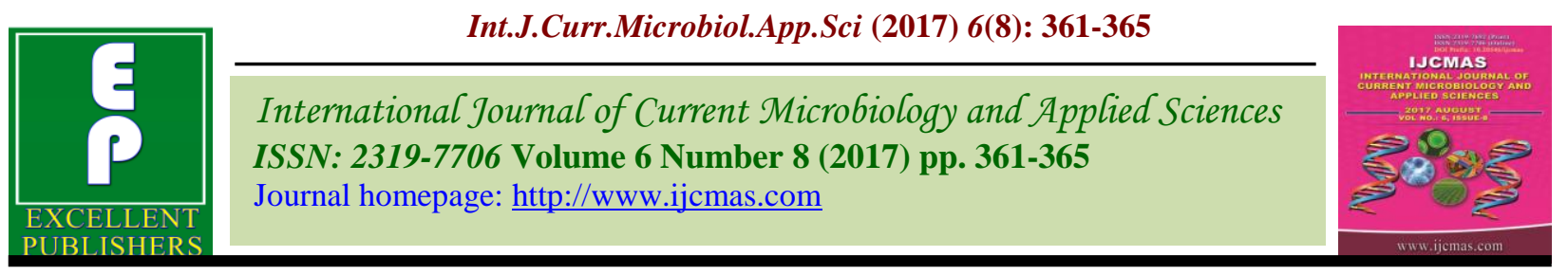

Original Research Article

https://doi.org/10.20546/ijcmas.2017.608.048

\title{
Socio-Economic Status of Brinjal Growers in Bulandshahr District of Western Uttar Pradesh, India
}

\author{
A.S. Maurya ${ }^{1 *}$, R.N. Yadav ${ }^{1}$, D.K. Singh ${ }^{1}$, D. Singh ${ }^{1}$, V.K. Singh ${ }^{1}$, \\ Prerana Kaushal $^{2}$ and Manoj Kumar Singh ${ }^{3}$
}
${ }^{1}$ Department of Agricultural Extension and Communication, SVPUA\&T, Modipuram, Meerut, (U.P.) - 250110, India
${ }^{2}$ Department of Home Science Extension, BHU, Varanasi, (U.P.) - 251001, India
${ }^{3}$ Department of Horticulture, SVPUA\&T, Modipuram, Meerut, (U.P.) - 250110, India
*Corresponding author

\section{A B S T R A C T}

The present investigation was carried out during the year 2016-17 in Bulandshahr district of Western Uttar Pradesh to know the socio-economic status of brinjal growers. Bulandshahr district comprise of 16 blocks in which two blocks namely Lakhoti and Jahangirabad were purposively selected. Four villages namely Dhakka, Dhakroli from lakhoti block and Shekhpur, Pasoli selected from Jahangirabad block. From the selected each village's 20 respondents were selected randomly, thus a total of 80 brinjal growers

\section{Keywords}

Socio-economic status, Brinjal growers.

\section{Article Info}

Accepted:

04 June 2017

Available Online:

10 August 2017 constituted the sample size for the study and data were collected by means of personal interview with the help of pre structured schedule. The study depicted that the majority of the brinjal growers were found upper middle age category group of 46-60 years (42.50 per cent), other backward caste (62.50 per cent), high school (31.25 per cent), married (93.75per cent), joint families (62.50 per cent), families size of medium category 5 to 8 members (50.00 per cent), no social participation ( 75.00 per cent), medium land holding size category of respondents with 4-10 hectare (28.75 per cent), pucca type of housing pattern $(83.75$ per cent). It was also observed that the maximum respondents were use as small dairy size ( 73.75 per cent). The maximum brinjal growers $(48.75$ per cent) were having resource poor, medium family resources (66.25 per cent), transport facilities for loading were jhota buggy ( 81.25 per cent), and source of irrigation was canal (30.00 per cent). It was also observed that agriculture is main occupation (91.25 per cent), and service as subsidiary occupation with (06.25 per cent), respectively. Respondents were found such who had the earning annual income of Rs. above 1,50,000/-. It was found maximum respondents (51.25 per cent) using medium level of information sources, had medium level of scientific orientation ( 48.75 per cent), and medium level of risk orientation (60 per cent).

\section{Introduction}

Vegetables are grown in India since thousands of years but now-a-days it has become an important enterprise at national and inter-national level. In recent years, the vegetables has become as an essential requirement of the daily human diet, because of its nutritional value. Regular use of vegetables provides us most of the essential health building and protecting substances, such as vitamins and minerals. In India where 
vegetarianism has been a way of life, since, the early days of recorded history, the problem of under nutrition and malnutrition can only be solved through balanced diet for which vegetables are essential component of the daily diet. Brinjal (Solanum melongena L.) or eggplant is one of the most common popular and principle vegetable crops grown in India and other parts of the world. The brinjal is of most importance in the warm areas of Far-East, being grown extensively in India and other Asian countries like Bangladesh and Pakistan. Other major brinjal producing countries are China, Turkey, Japan, Indonesia and Spain. The cultivated brinjal is of Indian origin and has been in cultivation for long time (Thompson and Kelly, 1957). Vavilov (1928) was of the opinion that its centre of origin was in the Indo-Burman region.

Egg-plant or brinjal (Solanum melongena L.) is a hardy plant compared to other vegetables grown in Sri-Lanka. Because of its hardiness, it can be successfully grown in very dry areas under rain-fed conditions or with minimum irrigation facilities. Egg-plant can be kept for more than one year in production by pruning at the end of the harvesting season. The fruit colour varies from pure white to dark purple or black in different varieties. Eggplant is an important source of antioxidants, vitamins, and minerals (Gramazio et al., 2014). The most important nutritional components of eggplant are phenolic compounds that give the fruit its antioxidant properties (Plazas et al., 2013) which are beneficial for a number of metabolic and cardiovascular ailments. Breeding objectives for eggplant are mostly oriented toward developing high-yielding, early maturing, and high fruit-quality varieties, along with stress resistance and high antioxidants

This crop can be grown throughout the year in all Agro-climatic regions except up country- wet zone. Grows well up to an elevation of about $1300 \mathrm{~m}$ in low country wet zone, Intermediate, up country intermediate and dry zone. Eggplant is tolerant to drought. Well drain, light soils with a $\mathrm{pH}$ of 5.5-5.8 are more suitable for the cultivation in India. India contributes 8703.8 metric tonnes to the global production of brinjal and ranks second next to China. Brinjal occupies third position among vegetable crops in India and covers 9 per cent of total vegetable production in India. Brinjal is highly productive and usually find its place as poor man's crop. Brinjal fruits are fairly good source of $\mathrm{Ca}, \mathrm{O}, \mathrm{Fe}$ and Vitamins particularly " $\mathrm{B}$ " group and $\mathrm{C}$. It is reported to stimulate the intrahepatic metabolism of blood cholesterol. It is also got much potential as raw material in pickle making and dehydration industries.

\section{Materials and Methods}

This study was conducted in Bulandshahr district of Western Uttar Pradesh during the year 2016-17. Bulandshahr district comprise of 16 blocks in which two blocks namely Lakhoti and Jahangirabad were purposively selected.

Two villages selected from each blocks. From the selected each village's 20 respondents were selected randomly, thus a total of 80 brinjal growers constituted the sample size for the study. The data were collected through personal interview with the help of pre structured schedule. The data were analysed and find out the percentage and rank order.

\section{Results and Discussion}

The socio-economic status of brinjal growers was studied and data have been given in table 1. The data of socio-economic status of brinjal growers are presented in table 1 the result revealed that the majority of the brinjal growers (42.50 per cent) were belonged to 
age group of 46-60 years. The education status revealed that 31.25 per cent of high school level of education belonged to other backward castes 62.50 per cent. The majority of brinjal growers (62.50 per cent) belonging to joint family system and the majority of respondents (50.00 per cent) were having 5 to 8 members in family. The data also shows that maximum number of brinjal growers (75.00 per cent) having not participation in any organizational or social activities, The land holding size revealed that maximum brinjal growers (28.75 per cent) belonged to 4 to 10 hectare land holding size and the majority of brinjal growers (83.75 per cent) were having pucca type of housing pattern.

It was also observed that the maximum brinjal growers (73.75 per cent) were use as small dairy. The maximum brinjal growers (48.75 per cent) were having resource poor, medium family resources (66.25 per cent), transport facilities for loading were jhota buggy $(81.25$ per cent) and as source of irrigation was canal (30.00 per cent). It was also observed that agriculture is main occupation (91.25 per cent) and service as subsidiary occupation with (06.25 per cent), respectively.

Table.1 Distribution of the brinjal growers according to their socio-economic status N=80

\begin{tabular}{|l|c|c|}
\hline Socio-economic status of brinjal growers & \multicolumn{2}{|c|}{ Brinjal growers } \\
\hline Age categories (years) & Frequency & Percentage \\
\hline Young (15- 30) & 10 & 12.50 \\
\hline Lower Middle (31 to 45) & 26 & 32.50 \\
\hline Upper Middle (46-60) & 34 & 42.50 \\
\hline Old age (above 60) & 10 & 12.50 \\
\hline Caste & & 27.50 \\
\hline General caste & 22 & 62.50 \\
\hline Other backward caste & 50 & 10.00 \\
\hline Scheduled caste/Sch. Tribe. & 08 & \\
\hline Education & & 2.50 \\
\hline Illiterate & 02 & 5.00 \\
\hline Can read and write & 04 & 8.75 \\
\hline Primary school & 07 & 15.00 \\
\hline Middle school & 12 & 31.25 \\
\hline High school & 25 & 16.25 \\
\hline Intermediate & 13 & 15.00 \\
\hline Graduate & 12 & 6.25 \\
\hline Post graduate and above & 05 & \\
\hline Marital status & & 93.75 \\
\hline Married & 75 & 6.25 \\
\hline Unmarried & 05 & 37.50 \\
\hline family type & & 62.50 \\
\hline Nuclear Family & 30 & 18.75 \\
\hline Joint Family & 50 & 50.00 \\
\hline Size of family & 15 & 31.25 \\
\hline Small (1- 4 members) & 40 & 75.00 \\
\hline Medium (5-8 members) & 25 & \\
\hline Large (more than 8 members) & & \\
\hline Social participation & & \\
\hline No participation & & \\
\hline & & \\
\hline & & \\
\hline
\end{tabular}




\begin{tabular}{|c|c|c|}
\hline Participation in one organization & 10 & 12.50 \\
\hline Participation in two organization & 7 & 8.75 \\
\hline Participation in more than two organization & 3 & 3.75 \\
\hline \multicolumn{3}{|l|}{ Land holding size } \\
\hline Marginal (below 1 ha) & 11 & 13.75 \\
\hline Small (1-2 ha) & 21 & 26.25 \\
\hline Semi Medium (2-4 ha) & 9 & 11.25 \\
\hline Medium (4-10 ha) & 23 & 28.75 \\
\hline Large (above $10 \mathrm{ha}$ ) & 15 & 18.75 \\
\hline \multicolumn{3}{|l|}{ Housing pattern } \\
\hline Mixed (Pucca + kuccha) & 13 & 16.25 \\
\hline Pucca & 67 & 83.75 \\
\hline \multicolumn{3}{|l|}{ livestock possession } \\
\hline Small dairy (1-3 milch animal) & 59 & 73.75 \\
\hline Medium dairy (4-6 milch animal) & 18 & 22.50 \\
\hline Big dairy (more than 6 milch animal) & 3 & 3.75 \\
\hline \multicolumn{3}{|l|}{ Farm assets } \\
\hline Resource poor $(<5)$ & 39 & 48.75 \\
\hline Resource medium (6 to 10$)$ & 32 & 40.00 \\
\hline Resource rich $(>10)$ & 9 & 11.25 \\
\hline \multicolumn{3}{|l|}{ Family resources } \\
\hline Low (Up to 5 materials) & 15 & 18.75 \\
\hline Medium (6 to 10 materials) & 53 & 66.25 \\
\hline High (Above 10) & 12 & 15.00 \\
\hline \multicolumn{3}{|l|}{ Transport facilities } \\
\hline Cycle & 48 & 60.00 \\
\hline Motorcycle/scooter & 59 & 73.75 \\
\hline Car & 7 & 8.75 \\
\hline Tractor trolley & 15 & 18.75 \\
\hline Bullock cart / jhota-buggy & 65 & 81.25 \\
\hline \multicolumn{3}{|l|}{ Irrigation facilities } \\
\hline Diesel engine & 16 & 20.00 \\
\hline Govt. Tube-well & 21 & 26.25 \\
\hline Private tube well & 19 & 23.75 \\
\hline Canal & 24 & 30.00 \\
\hline \multicolumn{3}{|l|}{ Occupation } \\
\hline Service & 05 & 06.25 \\
\hline Agriculture & 73 & 91.25 \\
\hline Business & 02 & 02.50 \\
\hline \multicolumn{3}{|l|}{ Annual income } \\
\hline Below Rs. 50,000/- & 2 & 2.50 \\
\hline Rs. 50,001-1,00,000/- & 7 & 8.75 \\
\hline Rs. $1,00,001-1,50,000 /-$ & 35 & 43.75 \\
\hline Above $1,50,000 /-$ & 36 & 45.00 \\
\hline \multicolumn{3}{|l|}{ Communication sources } \\
\hline Information poor (up to 4 sources) & 29 & 36.25 \\
\hline Information medium (5 to 8 sources) & 41 & 51.25 \\
\hline Information rich (more than 8 sources) & 10 & 12.50 \\
\hline Scientific orientation & & \\
\hline
\end{tabular}




\begin{tabular}{|l|c|c|}
\hline Low (up to 18 members) & 31 & 38.75 \\
\hline Medium (29 to 24) & 39 & 48.75 \\
\hline High (25 and above) & 10 & 12.50 \\
\hline Mean=19.38, S.D.=2.77, Min. =12, Max. =24 & & \\
\hline Risk orientation & & 23.75 \\
\hline Low (up to 17 members) & 19 & 60.00 \\
\hline Medium (18 to 22) & 48 & 16.25 \\
\hline High (23 and above) & 13 & \\
\hline Mean=19.57, S.D.=3.72, Min. =13, Max. =27 & & \\
\hline
\end{tabular}

Respondents were found such who had the earning annual income of Rs. above 1,50,000/-. It was found that maximum respondents $(51.25$ per cent) using medium level of information sources, had medium level of scientific orientation (48.75 per cent), and medium level of risk orientation (60 per cent).

It is concluded that majority of the respondents belonged to middle age group, other backward caste, married and literate.

These respondents had joint \& medium family, maximum number of respondents had no social participation, having pucca houses and medium size of land holding.

Most of the respondents having small dairy, resource poor, medium family resources, using canal as an irrigation facilities, having agriculture as main occupation with annual income range above Rs, 1,50,000/-. Information medium and medium level of scientific and risk orientation, respectively.

\section{Acknowledgement}

Author is thankful to Dr. R.N. Yadav, Professor, Department of Agricultural Extension\& Communication, SVP University of Agriculture and Technology, Modipuram,
Meerut-250110, (U.P.) India for his kind guidance, motivation and unconditional support for this work.

\section{References}

Badhe, D. K. and Saiyad, A. S. (2011) A study on knowledge of recommended production technologies among brinjal growers of Anand district of Gujarat. Agriculture Update; 6(3/4): 116-117.

Khare, N.K., Khare, Y.R. and Bairagi, B. (2001) the profile of vegetable growers. JNKVV Research Journal; publ. 2002. 35(1/2):99-101.

Saini, A. K. and Saini, K. S. (2015) Socioeconomic Profile of Farmers Supplying Horticultural Produce to a Vegetable Market in Punjab, Inter. Jour. Of Mang. And Soci. Sci. Res. 5(4):110-114.

Singh, D.K., Singh B.K., Yadav V.P.S. and Singh, L. (2010). Adoption behaviour of commercial vegetable growers in district Ghaziabad (U.P.). Indian Research Journal of Extension Education 10 (3): 66-70.

Walke, A.S., Khalache, P.G. and Gaikwad, J.H. (2009). Study of socio-personal, economic and psychological attributes and constraints faced by brinjal growers. Agriculture Update4 (1\&2): 204-206.

\section{How to cite this article:}

Maurya, A.S., R.N. Yadav, D.K. Singh, D. Singh, V.K. Singh, Prerana Kaushal and Manoj Kumar Singh. 2017. Socio-Economic Status of Brinjal Growers in Bulandshahr District of Western Uttar Pradesh. Int.J.Curr.Microbiol.App.Sci. 6(8): 361-365. doi: https://doi.org/10.20546/ijcmas.2017.608.048 